\title{
Effects of Local Shoreline and Subestuary Watershed Condition on Waterbird Community Integrity: Influences of Geospatial Scale and Season in the Chesapeake Bay
}

\author{
Diann J. Prosser ${ }^{1}$ (D) Jessica L. Nagel ${ }^{1} \cdot$ Shay Howlin $^{2} \cdot$ Paul R. Marbán $^{1} \cdot$ Daniel D. Day $^{1}$ • \\ R. Michael Erwin ${ }^{1,3}$
}

Received: 10 September 2016 / Revised: 30 June 2017 / Accepted: 3 July 2017 /Published online: 26 July 2017

(C) The Author(s) 2017, corrected publication 2019

\begin{abstract}
In many coastal regions throughout the world, there is increasing pressure to harden shorelines to protect human infrastructures against sea level rise, storm surge, and erosion. This study examines waterbird community integrity in relation to shoreline hardening and land use characteristics at three geospatial scales: (1) the shoreline scale characterized by seven shoreline types: bulkhead, riprap, developed, natural marsh, Phragmites-dominated marsh, sandy beach, and forest; (2) the local subestuary landscape scale including land up to $500 \mathrm{~m}$ inland of the shoreline; and (3) the watershed scale $>500 \mathrm{~m}$ from the shoreline. From 2010 to 2014, we conducted waterbird surveys along the shoreline and open water within 21 subestuaries throughout the Chesapeake Bay during two seasons to encompass post-breeding shorebirds and colonial waterbirds in late summer and migrating and wintering waterfowl in late fall. We employed an Index of Waterbird Community Integrity (IWCI) derived from mean abundance of individual waterbird species and scores of six key species attributes describing each species' sensitivity to human
\end{abstract}

Communicated by James Lovvorn

Electronic supplementary material The online version of this article (doi:10.1007/s12237-017-0288-0) contains supplementary material, which is available to authorized users.

Diann J. Prosser

dprosser@usgs.gov

1 U.S. Geological Survey, Patuxent Wildlife Research Center, Beltsville Lab, 10300 Baltimore Avenue, Beltsville, MD 20705, USA

2 Western EcoSystems Technology, 415 W. 17th Street, Suite 200 , Cheyenne, WY 82001, USA

3 Department of Environmental Sciences, Clark Hall, University of Virginia, Charlottesville, VA 22904, USA disturbance, and then used this index to characterize communities in each subestuary and season. IWCI scores ranged from 14.3 to 19.7 . Multivariate regression model selection showed that the local shoreline scale had the strongest influence on IWCI scores. At this scale, percent coverage of bulkhead and Phragmites along shorelines were the strongest predictors of IWCI, both with negative relationships. Recursive partitioning revealed that when subestuary shoreline coverage exceeded thresholds of approximately 5\% Phragmites or $8 \%$ bulkhead, IWCI scores decreased. Our results indicate that development at the shoreline scale has an important effect on waterbird community integrity, and that shoreline hardening and invasive Phragmites each have a negative effect on waterbirds using subestuarine systems.

Keywords Chesapeake Bay · Shoreline hardening • Waterbirds · Community integrity $\cdot$ Land use $\cdot$ Nearshore habitat

\section{Introduction}

Coastal shorelines represent an important ecological zone that is facing heightened anthropogenic pressure under coastal development. Throughout the world, coastal regions and estuaries like the Chesapeake Bay are increasingly undergoing a range of shoreline hardening conversions to protect human infrastructures against the threats of sea level rise, storm surge, and erosion (Bulleri and Chapman 2010; Dugan et al. 2011). Shoreline hardening or armoring typically involves installation of artificial structures such as wooden, concrete, or steel vertical bulkhead walls, or riprap borders consisting of piles of large stones or boulders. In the USA, it is estimated that approximately $14 \%$ of shorelines have been hardened, and this 
percentage has been projected to double by the year 2100 (Gittman et al. 2015).

While hardening of shorelines is designed to protect human property, shoreline development can have significant negative impacts on the extent and ecosystem integrity of estuarine and nearshore marine habitats. Ecological integrity refers to an ecosystem's capacity to support a diverse assemblage of organisms and maintain ecological functions while coping with changes in environmental conditions (Karr 1996). Installation of armored structures may reduce ecosystem integrity by contributing to loss of wetland habitat through the removal of natural vegetation along the shoreline (Dugan et al. 2011). Furthermore, the increases in both physical openings in disturbed soils and in availability of nutrients following installation may provide ideal conditions for colonization and expansion of the non-native haplotype of the reed Phragmites australis (hereafter Phragmites) (Minchinton and Bertness 2003; Silliman and Bertness 2004), leading to further degradation of tidal wetland habitat (King et al. 2007; Gedan et al. 2009; Sciance et al. 2016). Once installed, hardened shorelines alter hydrological regimes which may result in increased wave energy at the shoreline due to wave reflection (Hall and Pilkey 1991; Plant and Griggs 1992; Hardaway and Byrne 1999; Griggs 2005). This, in turn, can alter sediment composition (Miles et al. 2001) and lead to scouring and erosion of intertidal habitats located seaward of structures (Bozek and Burdick 2005; Dugan et al. 2008; Mattheus et al. 2010; Dethier et al. 2016), thereby reducing water clarity (Dugan et al. 2011). Permanent hardened structures also act as a barrier to the landward migration of natural shoreline habitats in response to sea level rise, leading to further loss of coastal habitat (Doody 2013; Pontee 2013). In addition to eliminating shallow water nursery habitat for many species, hardened shorelines support reduced diversity and abundance of fish and benthic invertebrates compared to natural habitats possibly due to reduced structural habitat complexity and food availability (Seitz et al. 2006; Bilkovic and Roggero 2008; Sobocinski et al. 2010; Long et al. 2011; Morley et al. 2012; Heerhartz et al. 2016).

Waterbird communities may also respond to changes in ecological integrity associated with shoreline hardening. Waterbirds include waterfowl, shorebirds, marsh birds, seabirds, and wading birds that rely on a wide range of estuarine and nearshore marine habitats throughout their life cycle (Erwin 1996; Ma et al. 2010). These species often occupy the highest trophic level in these ecosystems; therefore, changes observed within waterbird communities may be indicative of changes in habitat extent and quality as well as in food availability at lower trophic levels (Kushlan 1993; Stolen et al. 2005; Takekawa et al. 2006). Previous studies have shown that waterbirds respond to changes in ecological integrity associated with coastal urbanization and land use patterns at both local and regional scales (DeLuca et al. 2008; Smith and Chow-Fraser 2010; Studds et al. 2012). However, few studies have explored the effects of shoreline hardening and associated changes in habitat quality and extent on waterbird communities directly (Dugan and Hubbard 2006; Ludwig et al. 2010).

The Chesapeake Bay is a large estuary characterized by thousands of kilometers of coastline and wetlands that provide essential staging, wintering, and breeding habitat for waterbirds on the Atlantic coast of North America (Erwin 1996). In recent decades, the use of shoreline armoring has expanded throughout Chesapeake Bay, with hundreds of miles of shorelines hardened (Titus 1998; Hardaway and Byrne 1999). In some areas, $50 \%$ or more of shorelines have been armored (Patrick et al. 2014; Gittman et al. 2015). Armoring in this region is expected to increase in coming years in response to expanding urban development and regional sea level rise that is twice the global rate (Titus et al. 2009; Gittman et al. 2015). In light of the threat these changes pose to suitable habitat, there is an increasing need to explore how shoreline armoring affects waterbird communities in this region.

This study examines waterbird community integrity in Chesapeake Bay subestuaries in relation to shoreline hardening and land use characteristics at three geospatial scales: (1) the shoreline scale characterized by seven natural or developed shoreline types, (2) the local subestuary landscape scale including land up to $500 \mathrm{~m}$ inland of the shoreline, and (3) the subestuary watershed scale $>500 \mathrm{~m}$ from the shoreline. We employ a modified version (Prosser et al. 2017) of the Index of Waterbird Community Integrity (IWCI) developed by DeLuca et al. (2008) to characterize the waterbird community for each subestuary and used multivariate models to examine variation in index scores at three spatial scales. This index is based on each species' sensitivity to disturbance and has been used previously to describe the negative influence of anthropogenic land use on these communities (DeLuca et al. 2008; Studds et al. 2012). In addition, we explore the application of the IWCI across seasons, which innately targets differing groups of species (e.g., post-breeding shorebirds and colonial waterbirds in late summer vs. migratory and wintering waterfowl in late fall) (Erwin 1996).

\section{Methods}

\section{Study Area and Site Characterization}

The Chesapeake Bay is the largest estuary in the USA, with a surface area covering $11,600 \mathrm{~km}^{2}$ and a $\sim 166,000 \mathrm{~km}^{2}$ watershed spanning six states (New York, Pennsylvania, Delaware, Maryland, Virginia, and West Virginia) and Washington, D.C. The Bay is characterized by more than 100 subestuaries and $18,000 \mathrm{~km}$ of shoreline that support diverse communities of flora and fauna (Lippson and Lippson 2006). Land use along 
the Bay varies, with high-density urban development near the cities of Baltimore, Maryland, and Norfolk, Virginia; a mix of suburban development, agriculture, and mixed forest cover throughout the western shore of the Bay; and predominately commercial agriculture and silviculture throughout the eastern shore of Delaware, Maryland, and Virginia (Li et al. 2007).

Twenty-one subestuaries located throughout Chesapeake Bay (Fig. 1) were surveyed to characterize the waterbird community. We defined subestuaries as small embayments with distinct local watersheds and at least one perennial tributary (e.g., Li et al. 2007). We attempted to select subestuaries that represented a gradient in shoreline development as well as overall watershed land use (i.e., developed, agricultural, forested/wetland).

In order to determine at which spatial scale waterbird communities are most affected by shoreline development and land use characteristics, we investigated three levels (Fig. 2): (1) the subestuary shoreline scale (from the shoreline to $15 \mathrm{~m}$ inland, thereby measuring direct shoreline effects); (2) the local subestuary landscape scale including land within $500 \mathrm{~m}$ of the shoreline edge (measuring proximate effects of shoreline and local subestuary land use); and (3) the entire subestuary watershed scale $>500 \mathrm{~m}$ from the shoreline (measuring land use conditions across the watershed). Subestuary shorelines were first delineated using recent satellite imagery from Google Earth ${ }^{\mathrm{TM}}$ and ArcGISTM 10.2 according to the following seven habitat types: riprap, bulkhead, developed (e.g., homes, lawns), Phragmites-dominated marsh, natural marsh without Phragmites, forested, and sandy beach margin. Preliminary shoreline delineation was followed by groundtruthing the entire shoreline length via boat. The percentage of each shoreline type relative to total subestuary shoreline length $(\mathrm{km})$ was calculated from these estimates. Land use was obtained from the 2006 National Land Cover Database (NLCD) (Fry et al. 2011) and was estimated as a percentage of the following five land cover classes: developed, agricultural (cropland and pastures), grassland (dominated by herbaceous vegetation), forest, and wetland.

\section{Waterbird Surveys}

Surveys for waterbird community use were conducted in the 21 subestuaries over the course of 5 years (2010-2014). We surveyed three to six subestuaries per year, resulting in a single year of data for each subestuary. While this study design did not allow us to account for the possibility of inter-annual variation in waterbird abundance, it enabled us to survey more subestuaries representing a broader range in shoreline development and land use characteristics over the limited timeframe of the study. For the purpose of this study, we define waterbirds as species belonging to the following groups: waterfowl (e.g., ducks, geese, swans), shorebirds (e.g., sandpipers, plovers), marsh birds (e.g., rails, bitterns), seabirds (e.g., gulls, terns, cormorants), wading birds (e.g., herons, egrets, and ibises), raptors (only ospreys, Pandion haliaetus, and bald eagles, Haliaeetus leucocephalus), and selected perching birds often associated with water (e.g., belted kingfisher, Megaceryle alcyon, and fish crows, Corvus ossifragus). Although secretive marsh species were recorded when observed, we did not employ standard call-back techniques to detect these species (Conway and Gibbs 2005) and, therefore, omitted these species from analysis.

The Chesapeake Bay supports two distinct populations of Canada geese (Branta canadensis): a resident population that nests in the continental USA and a migratory population that nests in Canada and Alaska (Baldassarre 2014). Given differences in ranges, habitat use, feeding and nesting behavior, and sensitivity to human disturbance between these two groups (Dolbeer et al. 2014), we developed individual index scores for each of these two populations. We used the following guidelines to distinguish between these two morphometrically similar groups during our surveys: (1) Canada geese observed prior to mid-September were categorized as residents since migratory geese do not arrive in this region before then (Malecki et al. 2001); (2) after mid-September, we used behavioral characteristics to classify geese, with larger flocks or groups of individuals that exhibited skittish behavior or congregated in open water classified as migrants, and individuals or smaller groups observed along developed shorelines (e.g., lawns, etc.) that did not exhibit wariness to our passing boat classified as residents.

Waterbird surveys were performed by boat during two seasons in a given year: in late summer (1 August through 15 September) to capture the southbound migration of shorebirds and dispersal of post-breeding colonial waterbirds, and again in late fall (15 October to 15 December) to include migratory and wintering waterfowl. Three surveys per subestuary were performed during each season. Surveys were conducted during daylight hours (i.e., from 0700 to about $1700 \mathrm{~h}$ ), randomizing start times per site visit when possible. Days with high winds ( $>24 \mathrm{kph}$ ) and heavy precipitation were avoided to limit the potential impact of weather conditions on different survey days. To standardize for tide levels, we sampled during midtide to ebbing low (a $6 \mathrm{~h}$ window), and avoided conducting surveys during extreme high or low tides. Most subestuaries in Chesapeake Bay are microtidal (0.3-0.9 m tidal range), which minimized the effect of tide level on waterbird surveys.

Boat surveys were conducted parallel to the shorelines, within approximately $50 \mathrm{~m}$ from shore, to identify and count all waterbirds on the shore (and inland $15 \mathrm{~m}$ ), in the intertidal zone, or in shallow water, including those flying low $(<20 \mathrm{~m})$ over the survey area. During surveys, we maintained boat speeds of $<6 \mathrm{kph}$ to reduce disturbance and displacement of birds. Initially, we employed the double-observer method to ensure maximum inclusion of species (Nichols et al. 2000). However, since detectability of waterbird species was a 


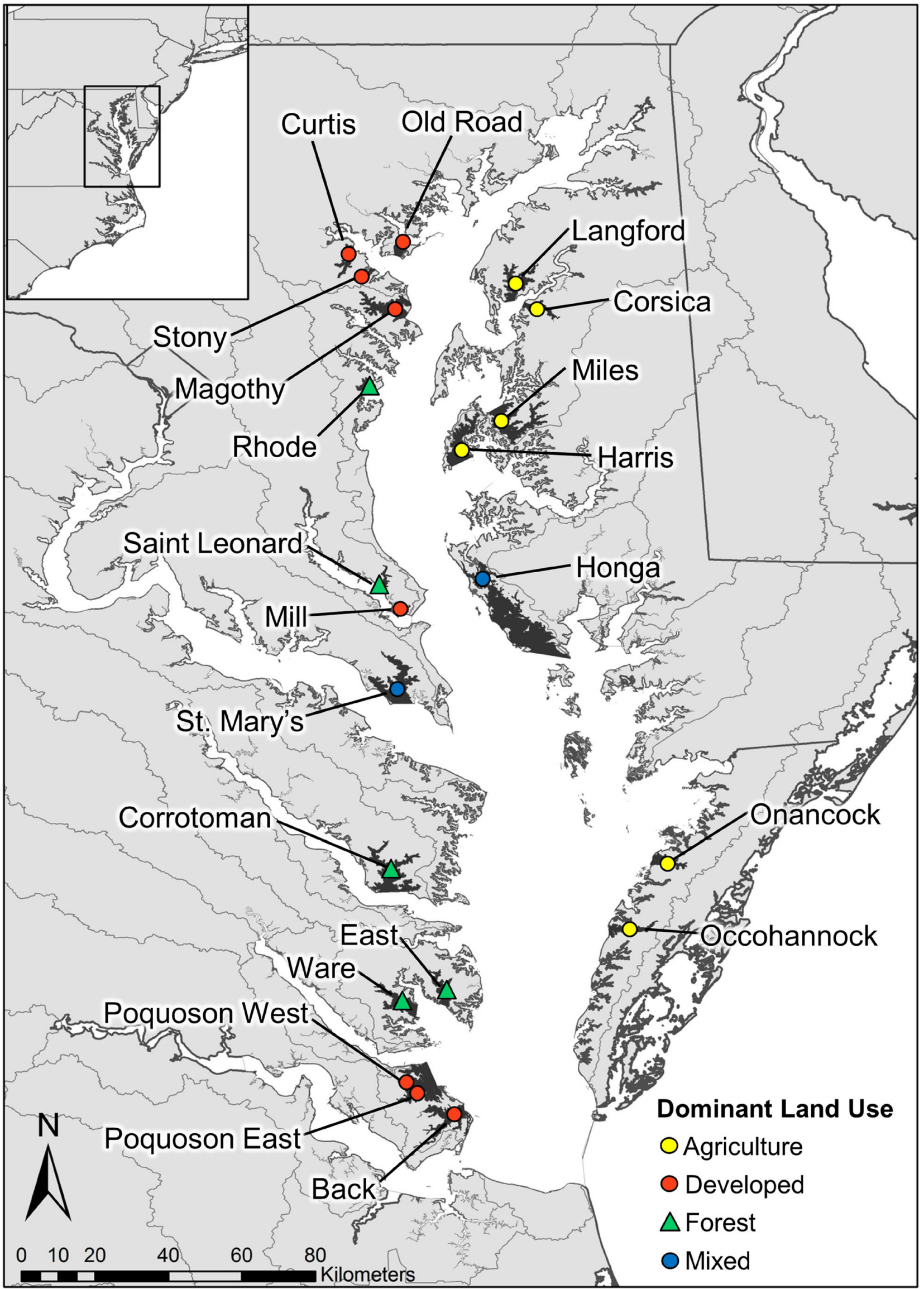


4 Fig. 1 Location of subestuaries surveyed for waterbirds in Chesapeake Bay. Subestuary watershed boundaries are shown in black. Dominant land use (agriculture, developed, forest, or mixed (a blend of two or more land use types)) in subestuary watersheds demarcated by colored circle or triangle

minimal concern due to their large size and visibility, single observers were often used with different individuals focusing on the shoreline, the open water side of the boat (within $100 \mathrm{~m}$ ), and overhead.

In addition to recording waterbirds along the shoreline, we performed open water surveys to develop a more complete profile of waterbird community use of the entire subestuary. Open water surveys were typically conducted immediately after the shoreline survey. We followed the midcourse of each subestuary and recorded all waterbirds observed in the mainstem of the subestuary at a distance $>100 \mathrm{~m}$ from shore to avoid double-counting birds observed during the main shoreline survey. For larger open water areas, we attempted to cover the entire open water area. Birds flushing within the area ahead of the boat were included in the counts, with care taken not to count them more than once.

\section{Calculation of IWCI}

To characterize the waterbird community in each subestuary, we utilized a modified version (Prosser et al. 2017) of the IWCI developed by DeLuca et al. (2008). The IWCI is derived from six attributes that reflect a given waterbird species' sensitivity to anthropogenic disturbance, including (1) foraging niche breadth, (2) nesting site selectivity, (3) migratory range, (4) breeding range, (5) conservation status, and (6) native status. DeLuca et al. (2008) provide the following justifications for including each attribute: foraging niche breadth, nesting site selectivity, and breeding range are included because birds exhibiting more limited variation of these aspects (i.e., highly specialized foraging habits or narrow breeding ranges) may be more susceptible to localized disturbances than birds with more generalized strategies

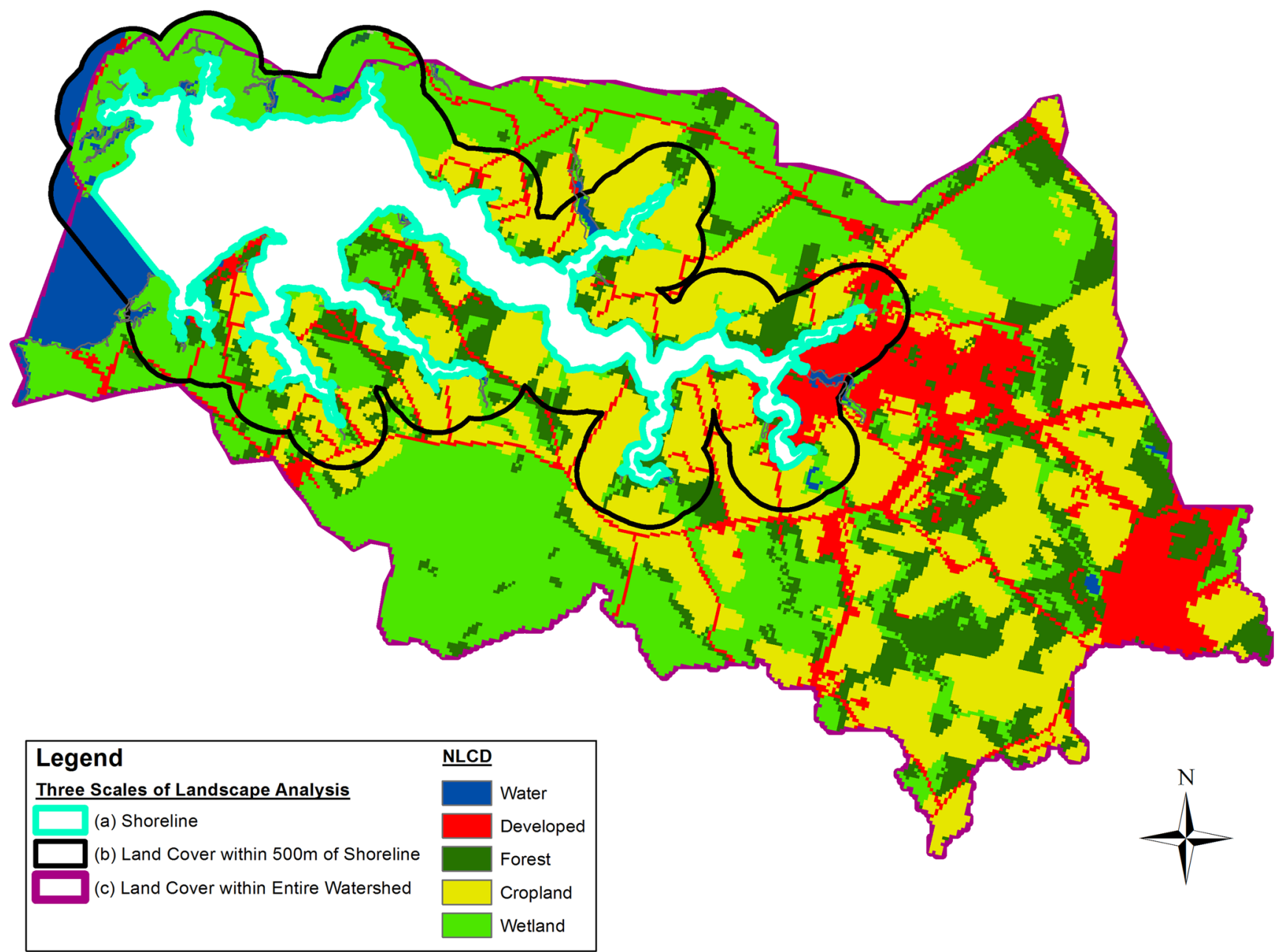

Fig. 2 Three scales of habitat analysis: (a) shoreline scale (turquoise boundary delineates the waterbird survey boundary which comprises the majority of each subestuary); (b) local subestuary landscape scale (500 $\mathrm{m}$ surrounding the shoreline edge); and (c) the regional watershed scale. Shoreline delineations were conducted using satellite imagery and ground-truthing via boat; $500 \mathrm{~m}$ and watershed landscape used National Land Cover Dataset (Fry et al. 2011) 
(Bryce et al. 2002; DeLuca et al. 2004; Ogden et al. 2014); migratory range is included because long-distance migrants have been shown to be sensitive to human disturbance (O'Connell et al. 2000; DeLuca et al. 2004); conservation status reflects local conservation concerns; and native status is included to reflect the presence of non-native species, which often indicate disturbed systems (Blair 1996; Duncan et al. 2003). Species attributes were generally scored on a scale from 1 to 4 , with lower scores reflecting disturbance-tolerant generalist species and higher scores reflecting disturbance-sensitive specialist species (Supplemental Table 1). Native status scores, however, were designated as either 0 (non-native) or 2 (native) to lower the relative importance of this attribute to the overall species score compared to the other attributes (Supplemental Table 1). For the aforementioned reasons, scores for species attributes relating to nesting site selectivity (generalist vs. moderate generalist) and migratory range (non-migratory vs. medium-distance migrant) differed for resident and migratory Canada goose populations (Prosser et al. 2017).

In order to calculate IWCI scores, we first determined species attribute scores for each species observed in each subestuary survey. Next, the score representing sensitivity to anthropogenic disturbance $\left(S_{\mathrm{IWCI}}\right)$ was calculated for each species as follows:

$S_{I W C I}=\sum_{i=1}^{6} L_{\mathrm{i}}$

where $L_{\mathrm{i}}$ is each species attribute score and $S_{\text {IWCI }}$ is the cumulative score of the six species attributes. Species with $S_{\text {IWCI }}$ scores $>10.5$ were considered sensitive to disturbance whereas species with scores $\leq 10.5$ were considered disturbancetolerant (Prosser et al. 2017). This was a slight change from the breakpoint of 10.0 used by DeLuca et al. (2008). Both were based on the range of index scores per species and associated natural history information. Finally, the IWCI score for each subestuary was calculated using the equation provided by DeLuca et al. (2008):

$I W C I=\left(\frac{\sum S_{I W C I}}{S_{\mathrm{N}}}\right)+(2) A_{\mathrm{I}}$

where the summation is across the $S_{\text {IWCI }}$ score for each species, $S_{\mathrm{N}}$ is the total number of species observed in a subestuary, and $A_{\mathrm{I}}$ is a species abundance estimate that is doubled to give it equivalent weight with the other variables in the equation. For abundance estimates, we calculated mean density of each species within a subestuary by averaging the number of birds observed and dividing by shoreline length $(\mathrm{km})$ in order to account for differences in areal extent among the subestuaries when estimating abundances. We calculated IWCI scores separately for both the late summer and late fall surveys to account for differences between post-breeding and migratory waterbird populations.

\section{Statistical Analyses}

We tested whether shoreline and landscape variables affected waterbird community integrity at the following scales: (1) the local shoreline scale (seven shoreline types), (2) the local subestuary landscape scale including land up to $500 \mathrm{~m}$ inland of the shoreline (five land use classes), and (3) the subestuary watershed scale (five land use classes) (Figs. 2 and 4). Our hypothesis was that shoreline characteristics or local land use may influence waterbird community integrity to a greater extent than regional watershed land use. After testing for normality, we fit linear multivariate statistical models for the IWCI scores with all three geospatial scales included as covariates. For both the late summer and late fall IWCI scores, we conducted a model selection routine using Akaike's information criteria $\left(\mathrm{AIC}_{\mathrm{c}}\right)$ adjusted for small sample size $(n=21)$ (Burnham and Anderson 2002). Backward stepwise selection was conducted starting with a full model containing all variables that were significant at an $\alpha$ of 0.20 in a univariate model. Quadratic terms were considered for inclusion in the full model if, for a given variable, a model containing both linear and quadratic terms had a better $\mathrm{AIC}_{\mathrm{c}}$ score than the model containing just the linear term. Steps of the backward model selection routine tested the removal of each variable to determine if the removal resulted in a decrease in the $\mathrm{AIC}_{\mathrm{c}}$. Each step of the model selection routine continued until the removal of a variable did not decrease the $\mathrm{AIC}_{\mathrm{c}}$. We checked for additional reductions in the model $\mathrm{AIC}_{\mathrm{c}}$ with the inclusion of quadratic terms, pairwise interactions, and three-way interactions among variables present in the model at the last step. Linear regression analysis was used to assess whether shoreline type or subestuary land use influenced IWCI scores, and a paired $t$ test was used to test for seasonal differences. All analyses were performed using the R (v. 3.3) statistical software (R Development Core Team 2016).

We also analyzed the data to see whether thresholds were evident between IWCI scores and key subestuary shoreline types. Thresholds, or changepoints beyond which IWCI scores were significantly affected, were estimated with a recursive partitioning approach with the threshold defined as the first node of a classification tree (Qian et al. 2003). The threshold was determined for each metric using the rpart package (Therneau et al. 2015) in R ( $R$ Development Core Team 2016). This method is useful for identifying nonlinear responses or thresholds that are not well captured by regression models (Maindonald and Braun 2010) and estimates the point resulting in the largest deviance reduction in IWCI scores. We resampled the 21 observations in each season's dataset with replacement to attain bootstrap confidence intervals for the threshold using the percentile method (Qian et al. 2003; Manly 2006). Significance of threshold results was judged with a chi-square test of significance with one degree of freedom. The null hypothesis of "no changepoint" was rejected if 
the threshold identified by recursive partitioning was better than a null model with no threshold.

\section{Results}

Sixty-four waterbird species were observed in the 21 Chesapeake Bay subestuaries surveyed in this study (Table 1), with 44 species recorded in late summer versus 51 species in late fall. Across all subestuaries, mean species richness in late summer and late fall was $18.9 \pm 0.75$ (SE) and $20.9 \pm 1.05$, respectively (see Supplemental Table 2 for species richness by site). The top five species by abundance for each season include: Summer-(1) laughing gulls, (2) mallards, (3) double-crested cormorants, (4) resident Canada geese, and (5) herring gulls; Fall-(1) migratory Canada geese, (2) resident Canada geese, (3) buffleheads, (4) mallards, and (5) ruddy ducks. For the 64 species observed, $S_{\text {IWCI }}$ scores ranged from 5 to 21 (Prosser et al. 2017), and included 11 disturbance-tolerant species $\left(S_{\mathrm{IWCI}} \leq 10.5\right)$ and 53 disturbance-sensitive species.

IWCI scores across subestuaries ranged from 14.3 to 19.7 for both seasons (Fig. 3). Lowest scores in late summer and late fall were observed at two subestuaries, Old Road and Stony, both of which had high percentages of hardened shorelines and developed land (Fig. 4). The highest scores (IWCI $>18$ in either season) were observed at Back, Ware, East, and Poquoson East in Virginia and Corsica in Maryland. Mean IWCI scores across all subestuaries were slightly lower $(P=0.057)$ in late summer $(16.9 \pm 0.27)$ relative to late fall $(17.4 \pm 0.21)$.

Significant negative relationships were observed between IWCI score and percent hardened shorelines (bulkhead + riprap) for both seasons (Fig. 5). Hardened shorelines represented less than $30 \%$ of total shoreline length for the majority (14 out of 21) of subestuaries surveyed (Fig. 4a). However, in four subestuaries (Old Road, Curtis, Stony, Mill), more than 55\% of the shoreline was hardened. These four subestuaries also had the highest percentages (48-89\%) of developed land at the local subestuary landscape scale within $500 \mathrm{~m}$ of the shoreline (Fig. 4b). In five subestuaries, including Old Road, Curtis, and Stony, developed land also represented more than $50 \%$ of land use at the subestuary watershed scale (Fig. 4c).

When deciding which variables to include in the full model for $\mathrm{AIC}_{\mathrm{c}}$ model selection (Table 2), we used a univariate regression between IWCI and shoreline or land cover, with $\alpha$ set to $<0.20$. At the shoreline scale, percentage of bulkhead, natural marsh, and Phragmites-dominated marsh were significant for the late summer season and were included in the full model. Percentage of bulkhead, riprap, and natural marsh were significant variables selected for the late fall season (Fig. 5). Land use characteristics at the local subestuary scale $(500 \mathrm{~m})$ that were significant included percentage of wetland in late summer and percentage of developed land in late fall. No variables at the watershed landscape scale were significant at $\alpha<0.2$, and thus none were included in the full model for $\mathrm{AIC}_{\mathrm{c}}$ selection.

Following $\mathrm{AIC}_{\mathrm{c}}$ model selection, the top model was reduced from five variables to two variables showing negative relationships between IWCI and percent bulkhead and Phragmites marsh for the late summer season $\left(\mathrm{IWCI}_{\text {summer }}=17.861-0.049(\%\right.$ bulkhead $)-0.048(\%$ Phragmites)). For the late fall season, the top model was reduced from four variables (full model) to a single variable, percent bulkhead, which also had a negative relationship with IWCI $\left(\mathrm{IWCI}_{\text {fall }}=17.778-0.0359(\%\right.$ bulkhead $\left.)\right)($ Fig. 6$)$. These results indicate significant variables only at the shoreline scale. Correlations above 0.75 , however, were noted between percent bulkhead and percentage of developed land at both the local subestuary $(500 \mathrm{~m})$ landscape $(r=0.88)$ and watershed scales $(r=0.79)$ even though these variables did not meet the $\alpha<0.2$ univariate cutoff for variable selection.

Our changepoint analysis suggests there are significant thresholds between IWCI scores and shoreline types included in the top $\mathrm{AIC}_{\mathrm{c}}$ model, as well as for the percent of hardened shoreline (bulkhead + riprap) within a subestuary. A similar threshold of approximately $8 \%$ bulkhead within a subestuary was identified for late summer $(P=0.006)$ and late fall $(P=0.036)$ (Fig. 7). A clear pattern can be seen at this changepoint where subestuaries with very little bulkhead (less than $8 \%$ ) have wide-ranging IWCI scores (from 16 to nearly 21 ), but as the amount of bulkhead increases, only IWCI scores less than 17.5 were observed. For percent Phragmites along the subestuary shoreline, a significant threshold of approximately 5\% was determined for the late summer season only $(P=0.004$ and $P=0.102$ for late summer and late fall, respectively). Finally, for percent hardened shoreline (bulkhead + riprap), significant thresholds were identified at approximately 31 and $26 \%$ for late summer and late fall, respectively $(P=0.005$ and $P=0.014)$ (Fig. 7).

\section{Discussion}

This large-scale study represents one of the first of its kind in assessing the effects of shoreline hardening on waterbird community integrity. In both late summer and late fall, IWCI scores decreased with increasing percentage of hardened shorelines (bulkhead + riprap), indicating a decline in disturbance-sensitive, specialist species. In general, the decline in waterbird community integrity associated with armoring of shorelines may be explained, in part, by the lack of natural vegetation required by waterbirds for foraging, nesting, and roosting (Boere et al. 2006) as well as by changes in prey abundance and diversity (Balouskus and Targett 2017; Seitz et al. 2017, this issue). In sandy beach environments, several 
Table 1 Waterbird species observed in Chesapeake Bay subestuaries from 2010 to 2014. Season of observation ( $\mathrm{S}=\mathrm{Late}$ Summer, F = Late Fall), IWCI scores, and disturbance tolerance designations (SENS $=$ Sensitive, DT $=$ Disturbance-tolerant) are shown for each species

\begin{tabular}{|c|c|c|c|c|}
\hline Common name & Scientific name & Season & IWCI score & Disturbance tolerance \\
\hline \multicolumn{5}{|l|}{ Accipitriformes } \\
\hline Bald Eagle & Haliaeetus leucocephalus & $\mathrm{S}, \mathrm{F}$ & 16.5 & SENS \\
\hline Osprey & Pandion haliaetus & $\mathrm{S}, \mathrm{F}$ & 14.5 & SENS \\
\hline \multicolumn{5}{|l|}{ Anseriformes } \\
\hline American Black Duck & Anas rubripes & $\mathrm{S}, \mathrm{F}$ & 15.5 & SENS \\
\hline Bufflehead & Bucephala albeola & $\mathrm{F}$ & 17 & SENS \\
\hline Canada Goose (migratory) & Branta canadensis & $\mathrm{S}, \mathrm{F}$ & 12 & SENS \\
\hline Canada Goose (non-migratory) & Branta canadensis & $\mathrm{S}, \mathrm{F}$ & 8.5 & DT \\
\hline Canvasback & Aythya valisineria & $\mathrm{F}$ & 16.5 & SENS \\
\hline Common Goldeneye & Bucephala clangula & $\mathrm{F}$ & 15.5 & SENS \\
\hline Common Merganser & Mergus merganser & $\mathrm{F}$ & 15 & SENS \\
\hline Domestic Duck & Anas platyrhynchos domesticus & $\mathrm{S}, \mathrm{F}$ & 5 & DT \\
\hline Domestic Goose & Anser anser domesticus & $\mathrm{S}, \mathrm{F}$ & 5 & DT \\
\hline Gadwall & Anas strepera & $\mathrm{F}$ & 15 & SENS \\
\hline Green-winged Teal & Anas crecca & $\mathrm{F}$ & 9 & DT \\
\hline Hooded Merganser & Lophodytes cucullatus & $\mathrm{F}$ & 15 & SENS \\
\hline Lesser Scaup & Aythya affinis & $\mathrm{F}$ & 14.5 & SENS \\
\hline Long-tailed Duck & Clangula hyemalis & $\mathrm{F}$ & 16 & SENS \\
\hline Mallard & Anas platyrhynchos & $\mathrm{S}, \mathrm{F}$ & 7 & DT \\
\hline Mute Swan & Cygnus olor & $\mathrm{S}, \mathrm{F}$ & 7.5 & DT \\
\hline Red-breasted Merganser & Mergus serrator & $\mathrm{F}$ & 15 & SENS \\
\hline Ring-necked Duck & Aythya collaris & $\mathrm{F}$ & 13 & SENS \\
\hline Ruddy Duck & Oxyura jamaicensis & $\mathrm{S}, \mathrm{F}$ & 16.5 & SENS \\
\hline Surf Scoter & Melanitta perspicillata & $\mathrm{F}$ & 18 & SENS \\
\hline Tundra Swan & Cygnus columbianus & $\mathrm{F}$ & 15.5 & SENS \\
\hline Wood Duck & Aix sponsa & $\mathrm{S}, \mathrm{F}$ & 14.5 & SENS \\
\hline \multicolumn{5}{|l|}{ Charadriiformes } \\
\hline American Oystercatcher & Haematopus palliatus & $\mathrm{S}$ & 16.5 & SENS \\
\hline Bonaparte's Gull & Chroicocephalus philadelphia & $\mathrm{F}$ & 13 & SENS \\
\hline Caspian Tern & Hydroprogne caspia & $\mathrm{S}$ & 15 & SENS \\
\hline Common Tern & Sterna hirundo & $\mathrm{S}$ & 19 & SENS \\
\hline Forster's Tern & Sterna forsteri & $\mathrm{S}, \mathrm{F}$ & 17.5 & SENS \\
\hline Great Black-backed Gull & Larus marinus & $\mathrm{S}, \mathrm{F}$ & 13.5 & SENS \\
\hline Greater Yellowlegs & Tringa melanoleuca & $\mathrm{S}, \mathrm{F}$ & 19.5 & SENS \\
\hline Herring Gull & Larus argentatus & $\mathrm{S}, \mathrm{F}$ & 7 & DT \\
\hline Killdeer & Charadrius vociferus & $\mathrm{S}, \mathrm{F}$ & 9.5 & DT \\
\hline Laughing Gull & Larus atricilla & $\mathrm{S}, \mathrm{F}$ & 17.5 & SENS \\
\hline Least Sandpiper & Calidris minutilla & $\mathrm{S}$ & 16 & SENS \\
\hline Least Tern & Sternula antillarum & $\mathrm{S}$ & 20.5 & SENS \\
\hline Red Knot & Calidris canutus & $\mathrm{S}, \mathrm{F}$ & 18.5 & SENS \\
\hline Ring-billed Gull & Larus delawarensis & $\mathrm{S}, \mathrm{F}$ & 9.5 & DT \\
\hline Royal Tern & Thalasseus maximus & $\mathrm{S}, \mathrm{F}$ & 21 & SENS \\
\hline Sanderling & Calidris alba & $\mathrm{S}, \mathrm{F}$ & 18.5 & SENS \\
\hline Sandwich Tern & Thalasseus sandvicensis & $\mathrm{S}$ & 21 & SENS \\
\hline Semipalmated Plover & Charadrius semipalmatus & $\mathrm{S}, \mathrm{F}$ & 17.5 & SENS \\
\hline Semipalmated Sandpiper & Calidris pusilla & $\mathrm{S}$ & 18.5 & SENS \\
\hline Short-billed Dowitcher & Limnodromus griseus & $\mathrm{S}, \mathrm{F}$ & 20 & SENS \\
\hline Spotted Sandpiper & Actitis macularius & $\mathrm{S}$ & 14.5 & SENS \\
\hline Western Sandpiper & Calidris mauri & $\mathrm{S}$ & 19 & SENS \\
\hline \multicolumn{5}{|l|}{ Coraciiformes } \\
\hline Belted Kingfisher & Megaceryle alcyon & $\mathrm{S}, \mathrm{F}$ & 14 & SENS \\
\hline \multicolumn{5}{|l|}{ Gaviiformes } \\
\hline Common Loon & Gavia immer & $\mathrm{F}$ & 16.5 & SENS \\
\hline \multicolumn{5}{|l|}{ Gruiformes } \\
\hline American Coot & Fulica americana & $\mathrm{F}$ & 12 & SENS \\
\hline \multicolumn{5}{|l|}{ Passeriformes } \\
\hline Fish Crow & Corvus ossifragus & $\mathrm{S}, \mathrm{F}$ & 8.5 & DT \\
\hline \multicolumn{5}{|l|}{ Pelecaniformes } \\
\hline Black-crowned Night Heron & Nycticorax nycticorax & $\mathrm{S}$ & 10.5 & SENS \\
\hline Brown Pelican & Pelecanus occidentalis & $\mathrm{S}, \mathrm{F}$ & 17 & SENS \\
\hline Great Blue Heron & Ardea herodias & $\mathrm{S}, \mathrm{F}$ & 12 & SENS \\
\hline Great Egret & Ardea alba & $\mathrm{S}, \mathrm{F}$ & 12.5 & SENS \\
\hline Green Heron & Butorides virescens & $\mathrm{S}$ & 12 & SENS \\
\hline Little Blue Heron & Egretta caerulea & $\mathrm{S}$ & 15 & SENS \\
\hline
\end{tabular}


Table 1 (continued)

\begin{tabular}{|c|c|c|c|c|}
\hline Common name & Scientific name & Season & IWCI score & Disturbance tolerance \\
\hline Snowy Egret & Egretta thula & $\mathrm{S}, \mathrm{F}$ & 14 & SENS \\
\hline Tricolored Heron & Egretta tricolor & $\mathrm{S}$ & 16 & SENS \\
\hline Yellow-crowned Night Heron & Nyctanassa violacea & $\mathrm{S}$ & 16 & SENS \\
\hline \multicolumn{5}{|l|}{ Podicipediformes } \\
\hline Horned Grebe & Podiceps auritus & $\mathrm{F}$ & 20 & SENS \\
\hline Pied-billed Grebe & Podilymbus podiceps & $\mathrm{F}$ & 14 & SENS \\
\hline Red-necked Grebe & Podiceps grisegena & $\mathrm{F}$ & 14 & SENS \\
\hline \multicolumn{5}{|l|}{ Suliformes } \\
\hline Double-crested Cormorant & Phalacrocorax auritus & $\mathrm{S}, \mathrm{F}$ & 9.5 & DT \\
\hline Northern Gannet & Morus bassanus & $\mathrm{F}$ & 15 & SENS \\
\hline
\end{tabular}

studies have observed reduced abundance and diversity of shorebirds along armored relative to unarmored beaches, and this response has been attributed to loss of upper beach and shallow water foraging zones as well as changes in prey availability associated with armoring (Dugan and Hubbard 2006; Dugan et al. 2008). The strongest indicator among all predictive variables was the percentage of bulkhead along shorelines, which was negatively related to IWCI scores. This is not necessarily surprising as the steep, vertical profile of bulkheads may provide reduced structural complexity to support invertebrates and fish for waterbird foraging (Chapman 2003) relative to other armored structures (e.g., riprap). Also, alterations to hydrodynamics associated with bulkheads may lead to increased scour and deepening of nearshore waters (Dugan et al. 2011), reducing shallow water foraging habitat for some waterbird species.

Our results also indicate a negative relationship between waterbird community integrity in late summer and the abundance of the invasive reed Phragmites along shorelines. Phragmites-dominated marshes may offer reduced habitat quality and function for some waterbird species. For example, waterbird species that require short, graminoid vegetation for foraging are often less abundant in marshes dominated by the taller, invasive reed (Benoit and Askins 1999). In addition, several studies have reported lower diversity or abundance of benthic macroinvertebrates (Angradi et al. 2001) and juvenile fish (Able and Hagan 2003) in Phragmites-dominated marshes, which may negatively impact some foraging waterbird species.

We found that of the three geospatial scales investigated, shoreline scale characteristics (i.e., shoreline type) had the greatest effect on IWCI scores. In univariate models, local subestuary $(500 \mathrm{~m})$ land use scale characteristics like the percent of wetland and percent of developed land showed significant relationships with IWCI, but the only variables (percent bulkhead and Phragmites marsh) that remained in the top models selected were from the shoreline scale, indicating that these variables had a stronger relationship with IWCI. A prime example of this was seen at Back River, a site with one of the highest percentages $(65 \%)$ of developed land within the
Fig. 3 IWCI scores for each subestuary in late summer and late fall for 21 subestuaries surveyed in the Chesapeake Bay, USA. Subestuaries are arranged in latitudinal order from north (Old Road Bay) to south (Back)

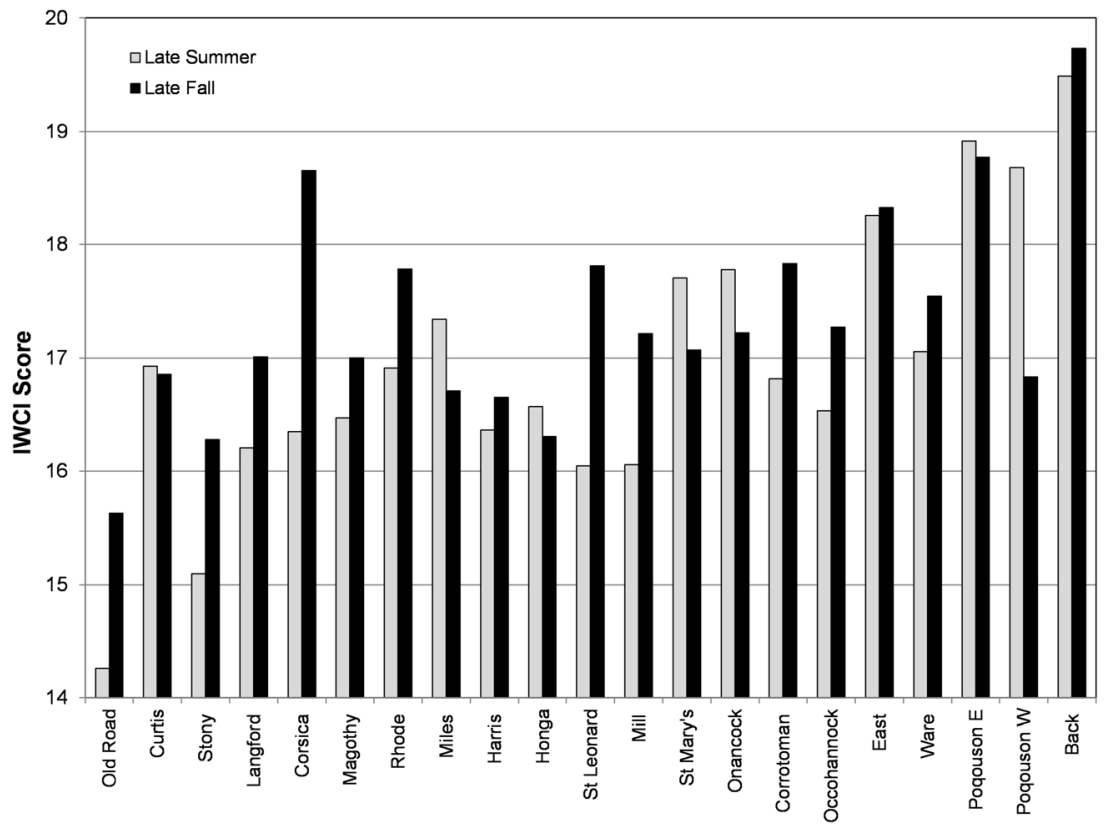


Fig. 4 a Percentage of shoreline type within each subestuary. $\mathbf{b}$ Percentage of local subestuary land use type in the $500 \mathrm{~m}$ surrounding the shoreline edge). c Percentage of land use type in the watershed surrounding each subestuary. Subestuaries are arranged in latitudinal order from north (Old Road Bay) to south (Back)

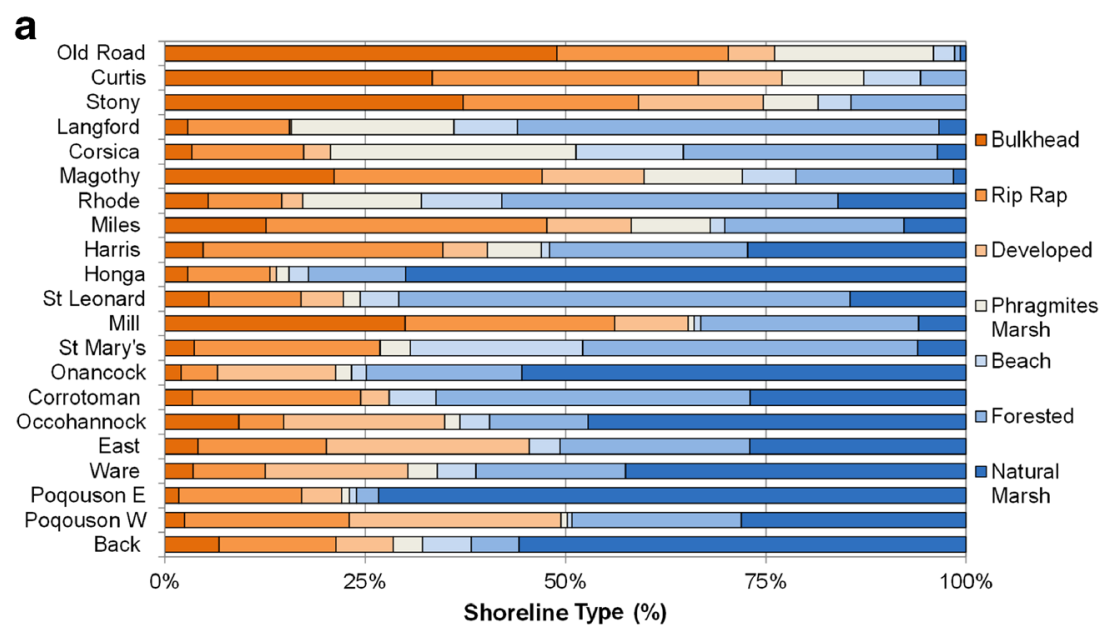

b

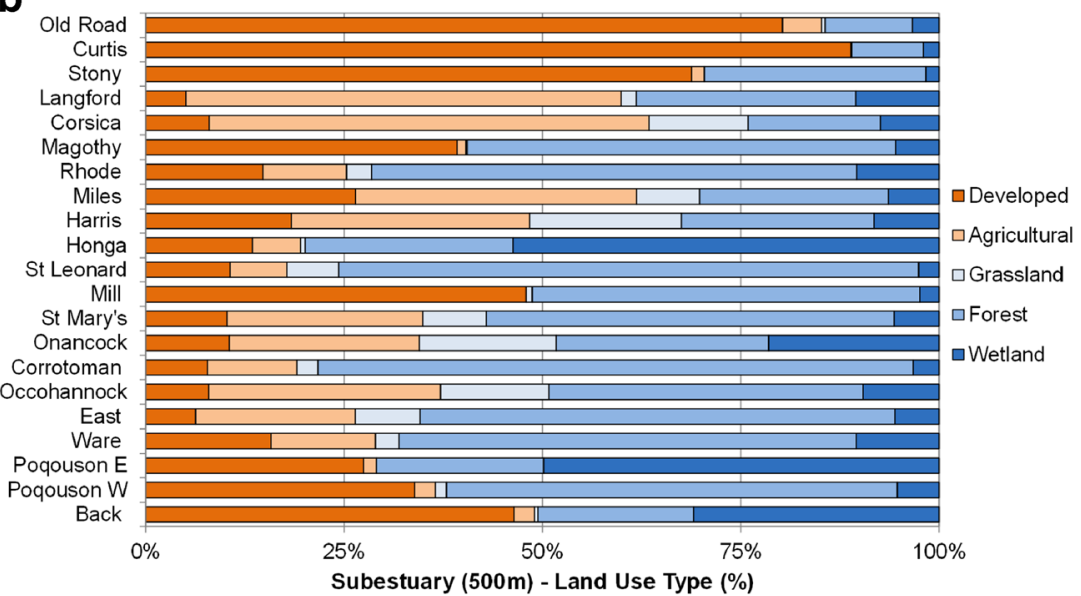

C

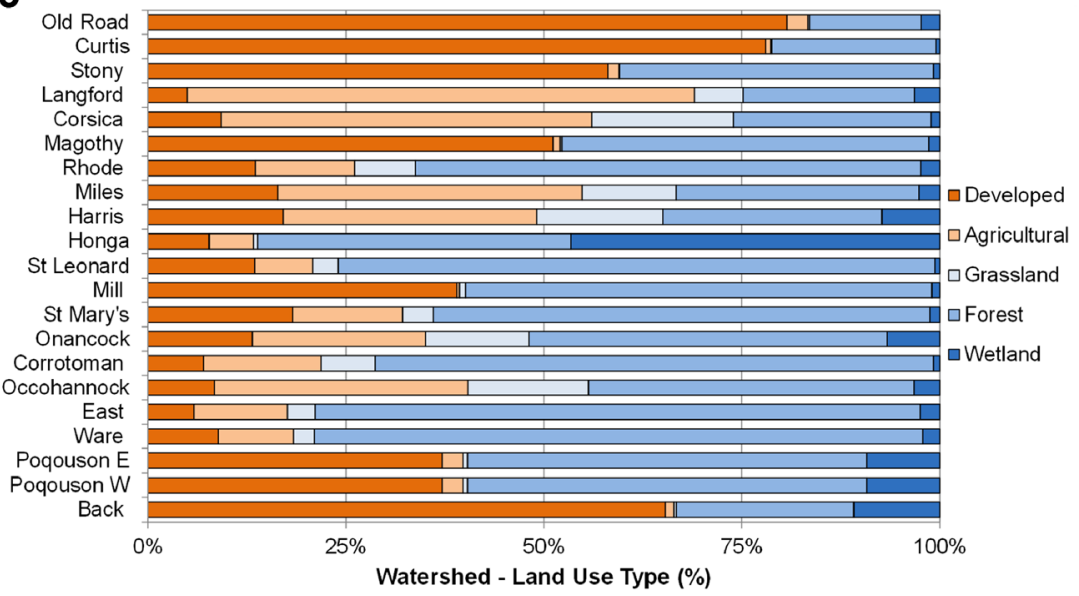

watershed but also the highest IWCI scores in both seasons. Greater than $60 \%$ of the shoreline in this subestuary is characterized by natural shorelines (marsh, beach, and forest) which may support disturbance-sensitive waterbirds locally despite high amounts of development at the watershed landscape scale.

Although development at the shoreline scale as measured as percent coverage of bulkheads was the strongest predictor of IWCI, the strong correlations between percent bulkhead and percentage of developed land at both the local subestuary $(500 \mathrm{~m})$ landscape and watershed scales suggest that development at these scales may also negatively impact waterbird community integrity. In their original study to develop the IWCI methodology in the Chesapeake Bay region, DeLuca et al. 2008 identified developed land cover at the local subestuary $(500 \mathrm{~m})$ landscape scale as the best predictor of 
Summer
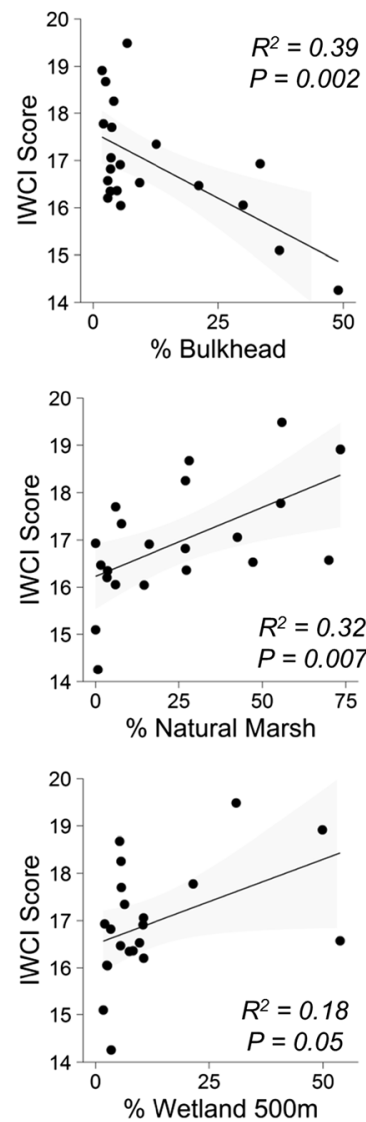
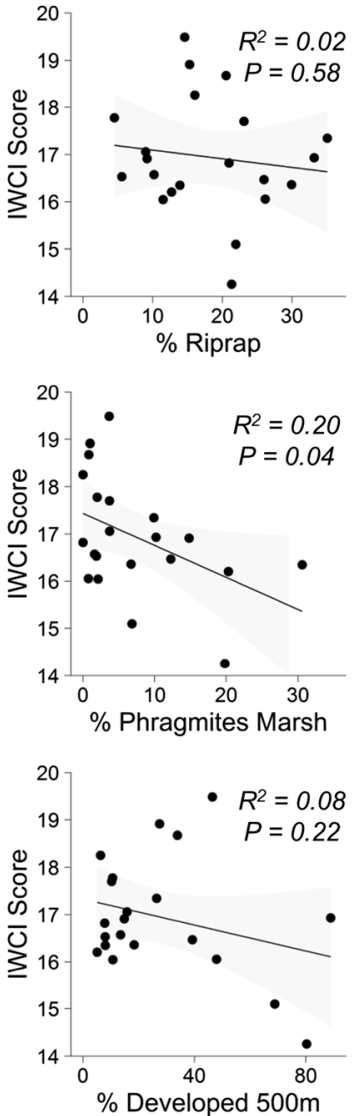

Fall
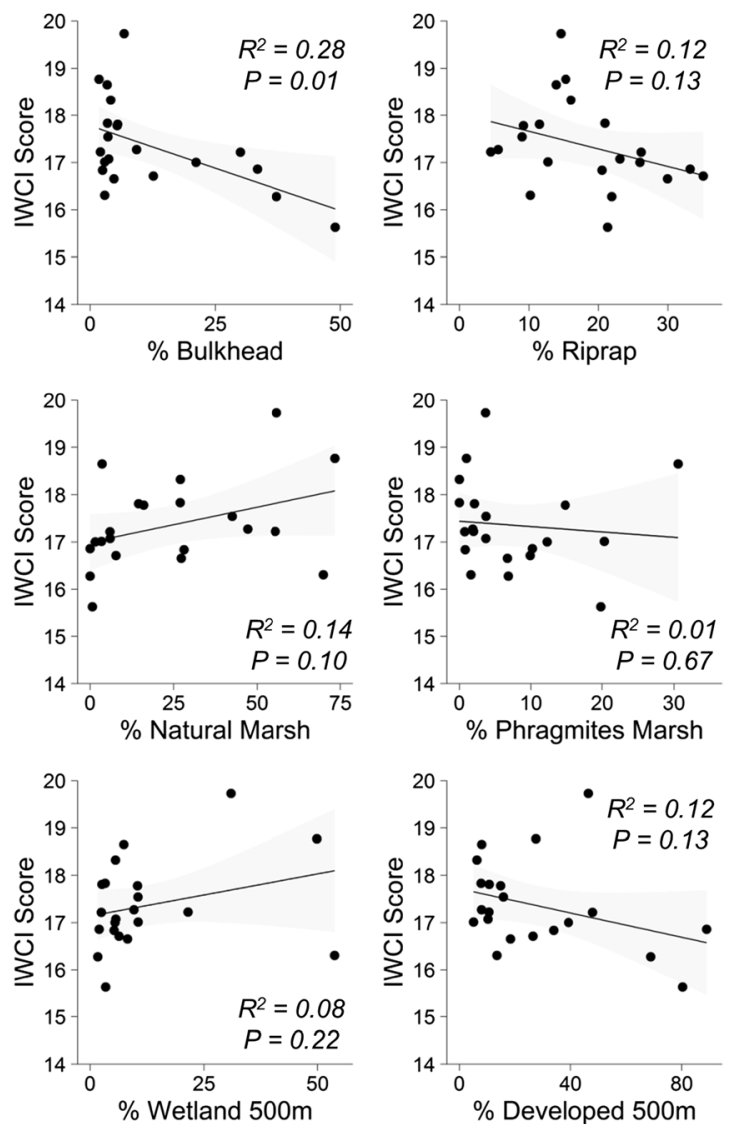

Fig. 5 Relationships between IWCI scores in late summer and late fall and shoreline and land use characteristics included in the full AIC $\mathrm{C}_{\mathrm{c}}$ models. Gray shading indicates $95 \%$ confidence intervals around the regression line. $R^{2}$ and $P$ values from linear regression analyses are also shown

breeding waterbird community integrity and that relationships between IWCI and predictors were stronger as the geospatial scale decreased (from watershed to $500 \mathrm{~m}$ ). However, their study did not investigate the effects of shoreline scale characteristics on IWCI. Other studies also have shown that waterbirds tend to respond to developed land use at the finer geospatial scales (DeLuca et al. 2004; Smith and Chow-Fraser 2010; McKinney et al. 2011; Schlacher et al. 2014). While the availability of suitable habitat and resources at local scales appear to be primary drivers of waterbird community integrity,

Table 2 Results of backward model selection for regression analysis between waterbird community index (IWCI as response) and subestuary shoreline type or local subestuary landscape scale (including land up to $500 \mathrm{~m}$ inland of the shoreline) land use predictors in summer versus fall

\begin{tabular}{|c|c|c|c|c|}
\hline Season & Model & AIC score & $\Delta \mathrm{AIC}_{\mathrm{c}}$ & $R^{2}$ \\
\hline \multirow[t]{4}{*}{ Late summer } & Null & 72.10 & - & - \\
\hline & Full model: bulkhead + Phragmites marsh + natural marsh + WETL500m $+(\text { WETL500m })^{2}$ & 69.95 & 2.15 & 0.62 \\
\hline & Step 2: bulkhead + Phragmites marsh + natural marsh & 66.70 & 3.25 & 0.50 \\
\hline & Step 3: bulkhead + Phragmites marsh & 63.94 & 2.76 & 0.49 \\
\hline \multirow[t]{5}{*}{ Late fall } & Null & 60.97 & - & - \\
\hline & Full model: bulkhead + riprap + natural marsh + DEV500m & 64.11 & 3.14 & 0.38 \\
\hline & Step 2: bulkhead + riprap + DEV500m & 60.36 & 3.75 & 0.38 \\
\hline & Step 3: bulkhead + DEV500m & 57.94 & 2.42 & 0.34 \\
\hline & Step 4: bulkhead & 56.90 & 1.04 & 0.28 \\
\hline
\end{tabular}

Shoreline type predictors (bulkhead, riprap, natural marsh, Phragmites marsh) are defined as a percentage of each shoreline type relative to total subestuary shoreline length $(\mathrm{km})$. The null model contains no covariates

AIC Akaike's information criterion scores for small sample sizes, $\triangle A I C_{c}$ difference in $\mathrm{AIC}_{\mathrm{c}}$ from the previous best model, WETL500m percentage of wetland in $500 \mathrm{~m}$ surrounding the subestuary, $D E V 500 \mathrm{~m}$ percentage of developed land in $500 \mathrm{~m}$ surrounding the subestuary 

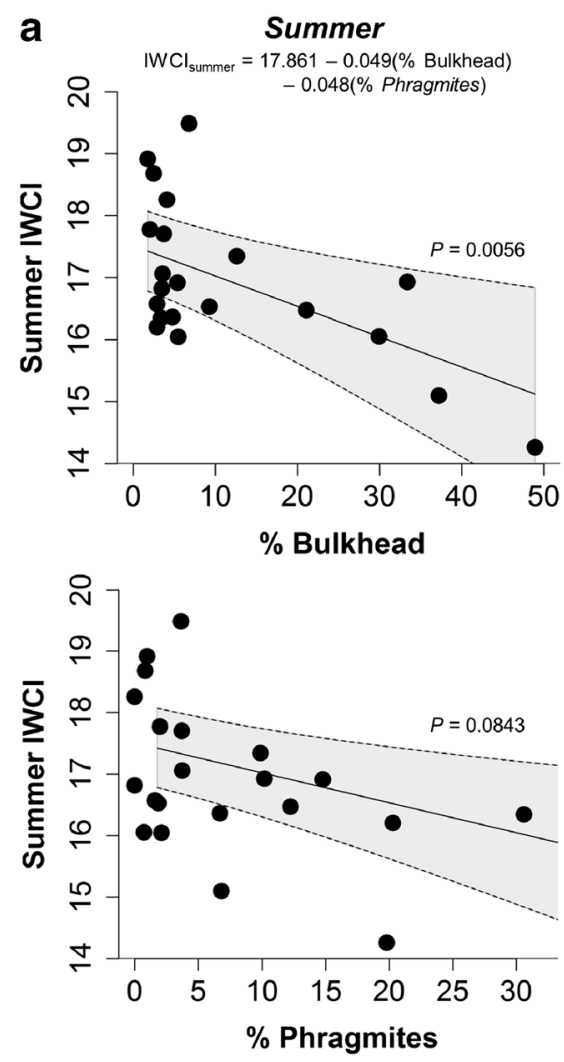

b

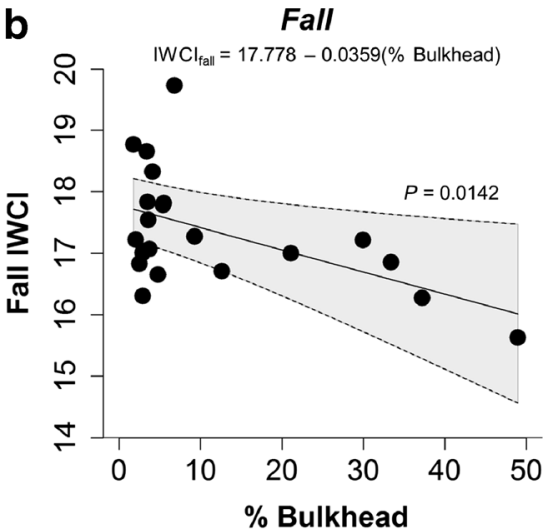

Fig. 6 Predictive plots of final models by $\mathrm{AIC}_{\mathrm{c}}$ backwards model selection for a late summer and $\mathbf{b}$ late fall seasons. Dashed lines and gray shading indicate $95 \%$ confidence intervals around the predictive regression line. $P$ values from analyses are also shown

urban and agricultural development at the watershed scale can negatively influence these species through stressors such as nutrients and toxins in runoff that may impact waterbirds directly (Kushlan 1993) or indirectly (Martínez et al. 2005; Studds et al. 2012), through reductions in prey abundance and diversity (Bilkovic et al. 2006). Moreover, local habitat fragmentation and loss may interact with these watershed level stressors to further influence waterbird community structure and function (Smith and Chow-Fraser 2010).

In this study, the response of waterbirds to shoreline hardening and local subestuary $(500 \mathrm{~m})$ land use differed between

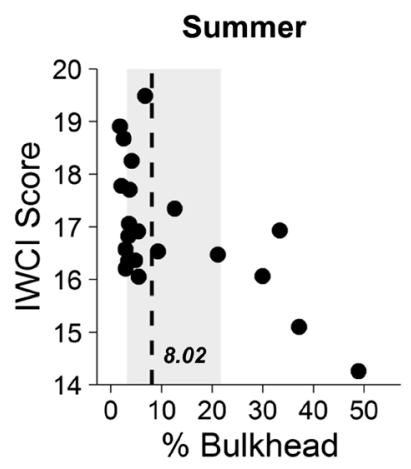

Fall
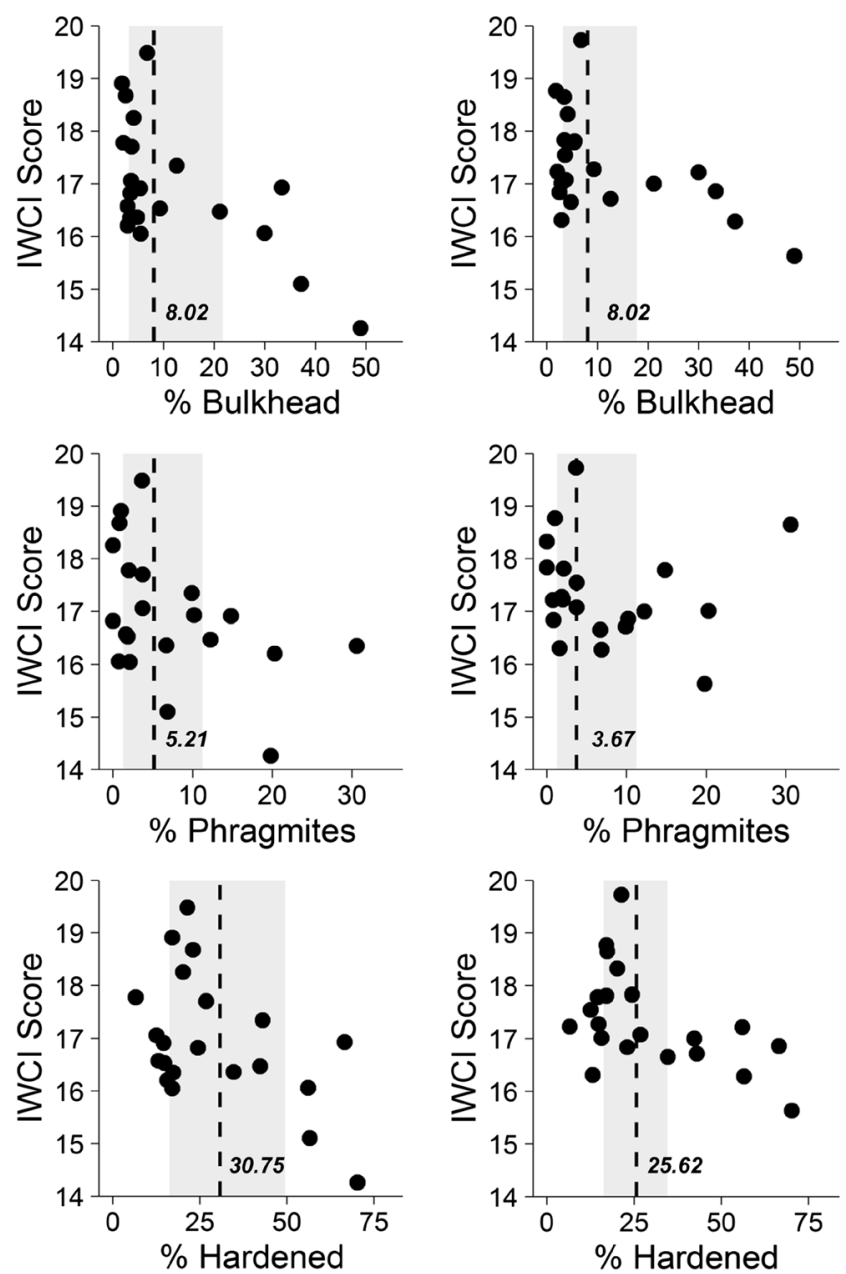

Fig. 7 Estimated thresholds (determined by recursive partitioning) between IWCI scores and the shoreline types included in the top $\mathrm{AIC}_{\mathrm{c}}$ models (\% bulkhead and \% Phragmites marsh) and percentage of hardened shorelines (bulkhead + riprap). Vertical dashed lines indicate the threshold estimate and gray shading indicates $95 \%$ confidence intervals around the threshold estimate

post-breeding (late summer) and migratory (late fall) populations. These seasonal differences may be related to differing habitat requirements for post-breeding versus migratory birds as well as changes in resources available between the two seasons. In addition, behavioral differences between these two groups may contribute to differences in habitat usage. For example, wintering waterbirds such as waterfowl exhibit more gregarious, mobile behavior than post-breeding birds, and their distribution may be driven more by shelter from winds and ice formation than food resources (Kear 2005).

Another potential factor influencing seasonal differences in our study is that the original IWCI developed by DeLuca et al. (2008) was designed to evaluate breeding waterbird community response to anthropogenic disturbance. Two of the six species attributes (nesting site selectivity and breeding range) used to calculate each species' tolerance to disturbance $\left(S_{\text {IWCI }}\right)$ relate to breeding strategies, which are not as likely to be 
relevant during late summer and late fall for post-breeding and migratory waterbirds, respectively. Although we are not aware of any data from behavioral studies that address how either breeding range or nest site selectivity of any avian groups relate to disturbance sensitivity outside of the breeding season, there are general patterns among waterbirds that strongly suggest an inverse relationship. The large breeding ranges and broad nest selectivity of disturbance-tolerant species such as herring gulls, mallards, double-crested cormorants, and mute swans compare well to their generalized habitat use and distribution (urban and suburban habitats) in nonbreeding seasons. In contrast, disturbance-sensitive species such as royal terns, American oystercatchers, dowitchers, and tundra swans have limited breeding ranges, demonstrate a high degree of nest site selectivity, and tend to be found less often in the highly disturbed suburban and urban areas in the non-breeding periods. As an exercise to see if the results would change if we excluded attributes for nest site selectivity and breeding range from the IWCI, we recalculated IWCI scores without those two attributes (using four vs. six species attributes). However, IWCI scores calculated using four species attributes were highly correlated with scores calculated using six species attributes in both late summer $(r=0.82)$ and late fall $(r=0.79)$, suggesting that our results would not change substantially if we excluded those attributes from the IWCI. As a future project, it would be interesting to test how changing the species attributes included in the index influence the ability of the IWCI to predict waterbird response to disturbance, especially for migratory birds.

In recent years, living shorelines have been developed as an alternative approach to traditional shoreline stabilization methods. This approach typically involves incorporating shoreline vegetation with sand, stone, and other organic or structural materials into a stabilizing design that strives to provide many of the ecological functions of natural shorelines. Recent studies have shown that, not only do living shorelines protect against scouring and erosion to a greater extent than traditional hardened shorelines (Currin et al. 2010; Gittman et al. 2014), they may also support greater abundances and diversity of faunal communities that more closely resemble natural ecosystems (Bilkovic and Mitchell 2013; Gittman et al. 2016). In the Chesapeake Bay region, the states of Maryland, Virginia, and Delaware are encouraging or mandating installation of living shorelines over traditional shoreline hardening techniques. It may be expected that living shorelines will have a positive influence on waterbird community integrity as they provide better habitat quality and resources relative to hardened shorelines. However, further research is required to assess how waterbirds respond to the living shoreline stabilization approach.
Given the importance of natural, nearshore habitats to waterbirds, the loss of these habitats represents a major concern for conservation of these species (Wilson et al. 2007; Ma et al. 2010; Erwin et al. 2011). With predicted expansion of shoreline armoring in response to both increasing urban development and sea level rise in the Chesapeake Bay region (Titus et al. 2009; Gittman et al. 2015), a major challenge for coastal zone managers will be to protect human infrastructure while preserving ecological services of these essential ecosystems. Our results indicate that waterbird community integrity is negatively influenced by local shoreline development and that further development may be detrimental to these communities.

Acknowledgements Funding for this study was provided by the National Oceanic and Atmospheric Administration (NOAA) Center for Sponsored Coastal Ocean Research (CSCOR). We thank Shane Heath, Bridget Collins, Peter Osenton, Brian Ho Sung Lee, Lisa Vormwald, and Mary Maxey for assistance with field surveys and Katherine Dale for assistance with graphics. The authors would like to thank Deanna Dawson and three anonymous reviewers for providing helpful comments to strengthen earlier versions of this manuscript. The use of trade, product, or firm names in this publication is for descriptive purposes only and does not imply endorsement by the US Government.

Open Access This article is distributed under the terms of the Creative Commons Attribution 4.0 International License (http://creativecommons. org/licences/by/4.0/), which permits use, duplication, adaptation, distribution and reproduction in any medium or format, as long as you give appropriate credit to the original author(s) and the source, provide a link to Creative Commons license and indicate if changes were made.

\section{References}

Able, Kenneth W., and Stacy M. Hagan. 2003. Impact of common reed, Phragmites australis, on essential fish habitat: influence on reproduction, embryological development, and larval abundance of mummichog (Fundulus heteroclitus). Estuaries 26: 40-50.

Angradi, Ted R., Stacy M. Hagan, and Kenneth W. Able. 2001. Vegetation type and the intertidal macroinvertebrate fauna of a brackish marsh: Phragmites vs. Spartina. Wetlands 21: 75-92.

Baldassarre, Guy A. 2014. Ducks, geese, and swans of North America. Baltimore, Maryland: Johns Hopkins University Press.

Balouskus, Richard G., and Timothy E. Targett. 2017. Impact of armored shorelines on shore zone fish in a mid-Atlantic, USA, estuary: modulation by hypoxia and temperature. Estuaries and Coasts.

Benoit, Lori K., and Robert A. Askins. 1999. Impact of the spread of Phragmites on the distribution of birds in Connecticut tidal marshes. Wetlands 19: 194-208.

Bilkovic, Donna M., and Molly M. Mitchell. 2013. Ecological tradeoffs of stabilized salt marshes as a shoreline protection strategy: Effects of artificial structures on macrobenthic assemblages. Ecological Engineering 61. Elsevier B.V.: 469-481. doi:10.1016/j.ecoleng. 2013.10.011.

Bilkovic, Donna M., and Molly M. Roggero. 2008. Effects of coastal development on nearshore estuarine nekton communities. Marine Ecology Progress Series 358: 27-39. doi:10.3354/meps07279.

Bilkovic, Donna M., Molly Roggero, Carl H. Hershner, and Kirk H. Havens. 2006. Influence of land use on macrobenthic communities 
in nearshore estuarine habitats. Estuaries and Coasts 29: 11851195. doi:10.1007/BF02781819.

Blair, Robert B. 1996. Land use and avian species diversity along an urban gradient. Ecological Applications 6: 506-519.

Boere, Gerard C., Colin A. Galbraith, and David A. Stroud. 2006. Waterbirds around the world. Edinburgh, U. K.: The Stationary Office.

Bozek, Catherine M., and David M. Burdick. 2005. Impacts of seawalls on saltmarsh plant communities in the Great Bay Estuary, New Hampshire USA. Wetlands Ecology and Management 13: 553-568. doi:10.1007/s11273-004-5543-z.

Bryce, Sandra A., Robert M. Hughes, and Philip R. Kaufmann. 2002. Development of a bird integrity index: Using bird assemblages as indicators of riparian condition. Environmental Management 30: 294-310. doi:10.1007/s00267-002-2702-y.

Bulleri, Fabio, and Maura G. Chapman. 2010. The introduction of coastal infrastructure as a driver of change in marine environments. Journal of Applied Ecology 47: 26-35. doi:10.1111/j.1365-2664.2009. 01751.x.

Burnham, Kenneth P., and David R. Anderson. 2002. Model Selection and Multimodel Inference: A Practical Information-Theoretic Approach. New York: Springer-Verlag.

Chapman, M.G. 2003. Paucity of mobile species on constructed seawalls: effects of urbanization on biodiversity. Marine Ecology Progress Series 264: 21-29.

Conway, Courtney J., and James P. Gibbs. 2005. Effectiveness of callbroadcast surveys for monitoring marsh birds. The Auk 122: 26-35. doi: $10.1126 /$ science. 98.2552 .466

Currin, Carolyn A, William S Chappell, and Anne Deaton. 2010. Developing alternative shoreline armoring strategies: the living shoreline approach in North Carolina. Shipman, H., Dethier, M.N., Gelfenbaum, G., Fresh, K.L., and Dinicola, R.S., eds., Puget Sound Shorelines and the Impacts of ArmoringProceedings of a State of the Science Workshop, May 2009.

DeLuca, William V., Colin E. Studds, Larry L. Rockwood, and Peter P. Marra. 2004. Influence of land use on the integrity of marsh bird communities of Chesapeake Bay, USA. Wetlands 24: 837-847. doi: 10.1672/0277-5212(2004)024[0837:IOLUOT]2.0.CO;2.

DeLuca, William V., Colin E. Studds, Ryan S. King, and Peter P. Marra. 2008. Coastal urbanization and the integrity of estuarine waterbird communities: Threshold responses and the importance of scale. Biological Conservation 141. Elsevier ltd: 2669-2678. doi:10. 1016/j.biocon.2008.07.023.

Dethier, Megan N., Wendel W. Raymond, Aundrea N. McBride, Jason D. Toft, Jeffery R. Cordell, Andrea S. Ogston, Sarah M. Heerhartz, et al. 2016. Multiscale impacts of armoring on Salish Sea shorelines: Evidence for cumulative and threshold effects. Estuarine, Coastal and Shelf Science 175. Elsevier Ltd: 106-117. doi:10.1016/j.ecss. 2016.03.033.

Dolbeer, Richard A., John L. Seubert, and Michael J. Begier. 2014. Population trends of resident and migratory Canada geese in relation to strikes with civil aircraft. Human-Wildlife Interactions 8: 88-99.

Doody, J. Patrick. 2013. Coastal squeeze and managed realignment in southeast England, does it tell us anything about the future? Ocean and Coastal Management 79. Elsevier Ltd: 34 41. doi:10.1016/j. ocecoaman.2012.05.008

Dugan, Jenifer E., and David M. Hubbard. 2006. Ecological responses to coastal armoring on exposed sandy beaches. Shore and Beach 74: 10-16. doi:10.1111/j.1439-0485.2008.00231.x.

Dugan, Jenifer E., David M. Hubbard, Ivan F. Rodil, David L. Revell, and Stephen Schroeter. 2008. Ecological effects of coastal armoring on sandy beaches. Marine Ecology 29: 160-170.

Dugan, Jenifer E., Laura Airoldi, Maura G. Chapman, S. J. Walker, and Thomas Schlacher. 2011. Estuarine and coastal structures: environmental effects, a focus on shore and nearshore structures. Treatise on Estuarine and Coastal Science. Vol. 8. Elsevier Inc. doi:10.1016/ B978-0-12-374711-2.00802-0.

Duncan, Richard P., Tim M. Blackburn, and Daniel Sol. 2003. The ecology of bird introductions. Annual Review of Ecology, Evolution, and Systematics 34: 71-98. doi:10.1146/annurev.ecolsys.34.011802. 132353.

Erwin, R. Michael. 1996. Dependence of waterbirds and shorebirds on shallow-water habitats in the mid-Atlantic coastal region: an ecological profile and management recommendations. Estuaries 19: 213219. doi: $10.2307 / 1352226$.

Erwin, R. Michael, David F. Brinker, Bryan D. Watts, Gary R. Costanzo, and David D. Morton. 2011. Islands at bay: Rising seas, eroding islands, and waterbird habitat loss in Chesapeake Bay (USA). Journal of Coastal Conservation 15: 51-60. doi:10.1007/s11852010-0119-y.

Fry, Joyce A., George Xian, Suming Jin, Jon A. Dewitz, Collin G. Homer, Limin Yang, Christopher A. Barnes, Nathaniel D. Herold, and James D. Wickham. 2011. Completion of the 2006 National Land Cover Database for the conterminous United States. Photogrammetric Engineering and Remote Sensing 77: 858-864.

Gedan, Keryn B., Brian R. Silliman, and Mark D. Bertness. 2009. Centuries of human-driven change in salt marsh ecosystems. Annual Review of Marine Science 1: 117-141. doi:10.1146/ annurev.marine.010908.163930.

Gittman, Rachel K., Alyssa M. Popowich, John F. Bruno, and Charles H. Peterson. 2014. Marshes with and without sills protect estuarine shorelines from erosion better than bulkheads during a Category 1 hurricane. Ocean and Coastal Management 102. Elsevier Ltd: 94 102. doi:10.1016/j.ocecoaman.2014.09.016.

Gittman, Rachel K., F. Joel Fodrie, Alyssa M. Popowich, Danielle A. Keller, John F. Bruno, Carolyn A. Currin, Charles H. Peterson, and Michael F. Piehler. 2015. Engineering away our natural defenses: An analysis of shoreline hardening in the US. Frontiers in Ecology and the Environment 13: 301-307. doi:10.1890/150065.

Gittman, Rachel K., Charles H. Peterson, Carolyn A. Currin, F. Joel Fodrie, Michael F. Piehler, and John F. Bruno. 2016. Living shorelines can enhance the nursery role of threatened estuarine habitats. Ecological Applications 26: 249-263. doi:10.1890/14-0716.1/ suppinfo.

Griggs, Gary B. 2005. The Impacts of Coastal Armoring. Shore \& Beach 73: $13-22$.

Hall, Mary Jo, and Orrin H. Pilkey. 1991. Effects of hard stabilization on dry beach width for New Jersey. Journal of Coastal Research 7: 771-785.

Hardaway, C. Scott, and Robert J. Byrne. 1999. Shoreline Management in Chesapeake Bay. Special Report in Applied Marine Science and Ocean Engineering Number 356. Virginia Sea Grant Publication VSG-99-11.

Heerhartz, Sarah M., Jason D. Toft, Jeffery R. Cordell, Megan N. Dethier, and Andrea S. Ogston. 2016. Shoreline Armoring in an Estuary Constrains Wrack-Associated Invertebrate Communities. Estuaries and Coasts 39: 171-188. doi:10.1007/s12237-015-9983-x.

Karr, James R. 1996. Ecological integrity and ecological health are not the same. In Engineering within ecological constraints, ed. Peter C. Schulze, 97-109. Washington, D.C.: National Academies Press.

Kear, Janet. 2005. Ducks, Geese, and Swans. In General Chapters and Species Accounts (Anhima to Salvadorina), vol. 1. New York: Oxford University Press.

King, Ryan S., William V. Deluca, Dennis F. Whigham, and Peter P. Marra. 2007. Threshold effects of coastal urbanization on Phragmites australis (common reed) abundance and foliar nitrogen in Chesapeake Bay. Estuaries and Coasts 30: 469-481. doi:10. 1007/BF02819393. 
Kushlan, James A. 1993. Colonial waterbirds as bioindicators of environmental change. Colonial Waterbirds 16: 223-251.

Li, Xuyong, Donald E. Weller, Charles L. Gallegos, Thomas E. Jordan, and Hae-Cheol Kim. 2007. Effects of watershed and estuarine characteristics on the abundance of submerged aquatic vegetation in Chesapeake Bay subestuaries. Estuaries and Coasts 30: 840-854. doi:10.1007/BF02841338.

Lippson, Alice Jane, and Robert L. Lippson. 2006. Life in the Chesapeake Bay: An Illustrated Guide to the Fishes, Invertebrates, Plants, Birds and Other Animals of Bays and Inlets from Cape Cod to Cape Hatteras. 3rd ed. Baltimore, Maryland: Johns Hopkins University Press.

Long, W. Christopher, Jacob N. Grow, John E. Majoris, and Anson H. Hines. 2011. Effects of anthropogenic shoreline hardening and invasion by Phragmites australis on habitat quality for juvenile blue crabs (Callinectes sapidus). Journal of Experimental Marine Biology and Ecology 409. Elsevier B.V.: 215-222. doi:10.1016/j. jembe.2011.08.024.

Ludwig, David F., Jacqueline Iannuzzi, Timothy J. Iannuzzi, and Joseph K. Shisler. 2010. Spatial and Temporal Habitat Use Patterns by Water Birds in an Urban Estuarine Ecosystem: Implications for Ecosystem Management and Restoration. Human and Ecological Risk Assessment 16: 163-184. doi:10.1080/10807030903459106.

Ma, Zhijun, Yinting Cai, Bo Li, and Jiakuan Chen. 2010. Managing wetland habitats for waterbirds: An international perspective. Wetlands 30: 15-27. doi:10.1007/s13157-009-0001-6.

Maindonald, John, and W. John Braun. 2010. Data Analysis and Graphics Using R: An Example-Based Approach. 3rd ed. Cambridge: Cambridge University Press.

Malecki, Richard A., Bruce D.J. Batt, and Susan E. Sheaffer. 2001. Spatial and temporal distribution of Atlantic population Canada Geese. Journal of Wildlife Management 65: 242-247.

Manly, Bryan F.J. 2006. Randomization, Bootstrap and Monte Carlo Methods in Biology. 3rd ed. London: Chapman and Hall.

Martínez, Fernández Julia, Miguel Angel Esteve Selma, Francisco Robledano Aymerich, María Teresa Pardo Sáez, and María Francisca Carreño Fructuoso. 2005. Aquatic birds as bioindicators of trophic changes and ecosystem deterioration in the Mar Menor lagoon (SE Spain). Hydrobiologia 550: 221-235. doi:10.1007/ s10750-005-4382-0.

Mattheus, Christopher R., Antonio B. Rodriguez, Brent A. McKee, and Carolyn A. Currin. 2010. Impact of land-use change and hard structures on the evolution of fringing marsh shorelines. Estuarine, Coastal and Shelf Science 88: 365-376. doi:10.1016/j.ecss.2010. 04.016 .

McKinney, Richard A., Kenneth B. Raposa, and Rose M. Cournoyer. 2011. Wetlands as habitat in urbanizing landscapes: Patterns of bird abundance and occupancy. Landscape and Urban Planning 100. Elsevier B.V.: 144-152. doi:10.1016/j.landurbplan.2010.11.015.

Miles, Jonathon R., Paul E. Russell, and David A. Huntley. 2001. Field Measurements of Sediment Dynamics in Front of a Seawall. Journal of Coastal Research 17: 195-206. doi:10.2307/4300163.

Minchinton, Todd E., and Mark D. Bertness. 2003. Disturbance-mediated competition and the spread of Phragmites australis in a coastal marsh. Ecological Applications 13: 1400-1416.

Morley, Sarah A., Jason D. Toft, and Karrie M. Hanson. 2012. Ecological Effects of Shoreline Armoring on Intertidal Habitats of a Puget Sound Urban Estuary. Estuaries and Coasts 35: 774-784. doi:10. 1007/s12237-012-9481-3.

Nichols, James D., James E. Hines, John R. Sauer, Frederick W. Fallon, Jane E. Fallon, and Patricia J. Heglund. 2000. A double-observer approach for estimating detection probability and abundance from point counts. The Auk 117: 393-408.

O'Connell, Timothy J., Laura E. Jackson, and Robert P. Brooks. 2000. Bird guilds as indicators of ecological condition in the central Appalachians. Ecological Applicationis 10: 1706-1721. doi:10.
1890/1051-0761(2000)010[1706:BGAIOE]2.0.CO;2.

Ogden, John C., John D. Baldwin, Oron L. Bass, Joan A. Browder, Mark I. Cook, Peter C. Frederick, Peter E. Frezza, et al. 2014. Waterbirds as indicators of ecosystem health in the coastal marine habitats of southern Florida: 1. Selection and justification for a suite of indicator species. Ecological Indicators 44: 148-163. doi:10.1016/j.ecolind. 2014.03.007.

Patrick, Christopher J., Donald E. Weller, Xuyong Li, and Micah Ryder. 2014. Effects of shoreline alteration and other stressors on submerged aquatic vegetation in subestuaries of Chesapeake Bay and the Mid-Atlantic coastal bays. Estuaries and Coasts 37: 1516-1531. doi:10.1007/s12237-014-9768-7.

Plant, Nathaniel G., and Gary B. Griggs. 1992. Interactions between Nearshore Processes and Beach Morphology Near a Seawall. Journal of Coastal Research 8: 183-200.

Pontee, Nigel. 2013. Defining coastal squeeze: A discussion. Ocean and Coastal Management 84: 1-4. doi:10.1016/j.ocecoaman.2013.07. 010.

Prosser, Diann J., Jessica L. Nagel, Paul R. Marban, Ze Luo, Daniel D. Day, and R. Michael Erwin. 2017. Standardization and application of an index of community integrity for waterbirds in the Chesapeake Bay, USA. Waterbirds 40.

Qian, Song S., Ryan S. King, and Curtis J. Richardson. 2003. Two statistical methods for the detection of environmental thresholds. Ecological Modelling 166: 87-97. doi:10.1016/S0304-3800(03) 00097-8.

R Development Core Team. 2016. R: A language and environment for statistical computing v. 2.15.1. R Foundation for Statistical Computing, Vienna, Austria. http://www.r-project.org/, accessed 10 October 2014.

Schlacher, Thomas A., Justin J. Meager, and Tara Nielsen. 2014. Habitat selection in birds feeding on ocean shores: Landscape effects are important in the choice of foraging sites by oystercatchers. Marine Ecology 35: 67-76. doi:10.1111/maec.12055.

Sciance, M. Benjamin, Christopher J. Patrick, Donald E. Weller, Meghan N. Williams, Melissa K. McCormick, and Eric L.G. Hazelton. 2016. Local and regional disturbances associated with the invasion of Chesapeake Bay marshes by the common reed Phragmites australis. Biological Invasions 18. Springer International Publishing: 2661-2677. doi:10.1007/s10530-016-1136-z.

Seitz, Rochelle D., Romuald N. Lipcius, N.H. Olmstead, Michael S. Seebo, and Debra M. Lambert. 2006. Influence of shallow-water habitats and shoreline development on abundance, biomass, and diversity of benthic prey and predators in Chesapeake Bay. Marine Ecology Progress Series 326: 11-27. doi:10.3354/meps326011.

Seitz, Rochelle D., Kathleen E. Knick, and Theresa M. Davenport. 2017. Upland use and shoreline development affect benthic community structure. Estuaries and Coasts.

Silliman, Brian R., and Mark D. Bertness. 2004. Shoreline development drives invasion of Phragmites australis and the loss of plant diversity on New England salt marshes. Conservation Biology 18: 1424 1434.

Smith, Lyndsay A., and Patricia Chow-Fraser. 2010. Impacts of adjacent land use and isolation on marsh bird communities. Environmental Management 45: 1040-1051. doi:10.1007/s00267-010-9475-5.

Sobocinski, Kathryn L., Jeffery R. Cordell, and Charles A. Simenstad. 2010. Effects of shoreline modifications on supratidal macroinvertebrate fauna on Puget sound, Washington beaches. Estuaries and Coasts 33: 699-711. doi:10.1007/s12237-009-9262-9.

Stolen, Eric D., David R. Breininger, and Peter C. Frederick. 2005. Using waterbirds as indicators in estuarine systems: successes and pitfalls. In Estuarine Indicators, ed. S.A. Bortone, 409-422. Boca Raton, Florida: CRC Press. 
Studds, Colin E., William V. DeLuca, Matthew E. Baker, Ryan S. King, and Peter P. Marra. 2012. Land cover and rainfall interact to shape waterbird community composition. PloS One 7: 1-10. doi:10.1371/ journal.pone.0035969.

Takekawa, John Y., A. Keith Miles, David H. Schoellhamer, Nicole D. Athearn, Michael K. Saiki, W.D. Duffy, S. Kleinschmidt, Gregory G. Shellenbarger, and Christopher A. Jannusch. 2006. Trophic structure and avian communities across a salinity gradient in evaporation ponds of the San Francisco Bay estuary. Hydrobiologia 567: 307327. doi:10.1007/s10750-006-0061-z.

Therneau, Terry, Beth Atkinson, and Brian Ripley. 2015. Rpart: Recursive partitioning and regression trees. $R$ package version 4 : $1-00$ http://CRAN.R-project.org/package=rpart.
Titus, James G. 1998. Rising seas, coastal erosion, and the takings clause: how to save wetlands and beaches without hurting property owners. Maryland Law Review 57: 1279-1399.

Titus, James G., Daniel E. Hudgens, Daniel L. Trescott, Michael Craghan, William H. Nuckols, Carl H. Hershner, J.M. Kassakian, et al. 2009. State and local governments plan for development of most land vulnerable to rising sea level along the US Atlantic coast. Environmental Research Letters 4: 044008. doi:10.1088/17489326/4/4/044008.

Wilson, Michael D., Bryan D. Watts, and David F. Brinker. 2007. Status Review of Chesapeake Bay Marsh Lands and Breeding Marsh Birds. Waterbirds 30: 122-137. doi:10.1675/1524-4695(2007) 030[0122:SROCBM $] 2.0 . \mathrm{CO} ; 2$. 